\title{
ANALYSIS OF TRENDS IN HOUSING CONSTRUCTION COST IN NIGERIA FROM 2000 - 2009
}

\author{
${ }^{1}$ Oke A. E, ${ }^{2}$ Ibironke O. T. and ${ }^{3}$ Evue, U. A. \\ Department of Quantity Surveying, Federal University of Technology, Akure, Nigeria \\ Emails: emayok@gmail.com and timothyibironke@gmail.com
}

\begin{abstract}
:
The upward trends in housing construction costs have been a major issue in the economy as a whole. The research uses typical 3-bedroom bungalow in Lagos to analyze the trends in housing construction cost from 2000 to 2009. The basic question for this research is whether the inflation in housing construction costs between 2000 and 2009 is statistically significant. The index number and one sample $t$ test were used to analyze the data. The findings show that costs maintained upward trends throughout the study period. The analysis shows that between 2000 and 2009, the average annual inflation in costs and inflation were significant at $11.27 \%$ and $268.88 \%$ respectively. The incessant increase in the cost of housing construction has contributed to shortage in housing supply leading to high cost of urban housing accommodation, construction estimates losing usefulness within short periods, difficulty in forecasting and planning and frequent contract price variations, which can lead to abandonment of projects. The recommendation is that government should execute policies to lower the inflation rates so that prices in the cost of housing materials would come down. Government should also provide public housing and appropriate infrastructure for the masses.
\end{abstract}

Keywords: construction cost, cost index, housing, inflation, trends, Nigeria

\section{Introduction}

A house or building occupies a unique place in the life of human beings; a person requires security, privacy and certain elements of personal identification, which a house can offer. House construction of any type is usually capital intensive and beyond the reach of the average income earner in Nigeria, this is often attributed to the high cost of labour and materials. The latter has been discussed severally by various authors and the ways to develop alternative building materials to produce cheaper and durable homes. It is no longer news that housing construction costs have been on the increase in cities such as Lagos, Abuja, Port Harcourt, Kaduna, Enugu, Ibadan and indeed, the whole of Nigeria. Udegbe (2005) noted that most people are not able to afford a house/home due to the high cost of production and materials, this is because the labour force e.g. Masons, Painters, Carpenters, Plumbers, Electricians, Site Labourers and others in the construction industry contribute to the production process in building and that it is not easy to employ these personnel because their charges are quite high. Udegbe (2005) further asserted that these labour costs have drastically increased the cost of building and so, reduced accommodation availability. The increase in the cost of construction have been noted to be excessive (Achuenu and Gunduri, 1998 and Abiola, 2000)

It is necessary to know the factors that affect housing construction costs in Nigeria in order to predict future levels. Knowledge of these factors would help to establish measures that could be taken to bring down the high cost of housing. This is important because not only is there acute shortage of housing, millions of middle and low income families are being priced out of the market for home ownership all across Nigeria (Windapo, 2004). In the past two decades, housing construction costs in Nigeria have shown continuous upward trends. Achuenu and Gundiri (1998) observe that increases 
in the cost of construction have been excessive. The Federal Office of Statistics, FOS, (1997), Nwuba (1992) and Abiola (2000) made similar observations. This increase in construction of housing has been a major social-economic issue in Nigeria for many years.

It has been estimated that building materials and components constitute between 50 to 60 percent of the total cost of construction (Okupe, 2000). It was further outlined that the factors contributing to this include inadequate infrastructural facilities like bad roads, which may increase the cost of delivery of materials and the tariffs charged on the materials that also shoot up the prices. Since the estimates of housing projects are determined largely by the cost of building materials involved, Okupe (2000) is of the view that most developers, individuals or corporate bodies have been compelled to use imported materials because of unavailability of generally acceptable local materials that can stand the test of time. Land is the main component of the shelter problem because it is the place where housing construction starts. Infrastructure includes roads, electricity, water, drainage, waste management and in some cases security. There is a certain degree of correlation between a house and its environment. For instance, the value of a house can be determined mostly by the nature and quality of its environment. Okupe (2000) noted that for turnkey housing development projects, infrastructure cost might take between 50 to 68 percent depending on the location and type of facilities proposed. Foreign components such as ironmongery, raw materials, machinery and equipment used in the production of building materials and in building construction have led to a prohibitive cost of the final building product after the devaluation of the Naira. It is probably one of the major reasons why private individuals and investors are unable to pay for the services of the construction industry.

Labour is used in every activity of construction such as setting out, foundation excavation, moulding and setting of blocks, pouring concrete, plastering, screeding, painting and so forth. The labour cost is determined by the skill and output of the worker and it is usually in two categories in the construction industry. The worker can be a skilled artisan or tradesman or a labourer. According to Udegbe (2005), most construction works are manually and crudely carried out in Nigeria, with less involvement of mechanical devices. He observed that the labour cost involved in the construction of two or three identical houses in the same location may not likely be the same due to different methodological approaches and technological/managerial competence. Capital/finance constitutes a fundamental centerpiece in any housing development project and the ability of a developer to mobilize enough funds for the project determines its success. Most developers in achieving the process of building houses for sale are forced to look for funds from many sources including financial institutions which most of the time charge the same interest rate required for other businesses for transactions involving housing construction. This paper established the extent of inflation in housing construction cost from 2000 to 2009 and the statistical significance of the inflations.

\section{Literature review Importance of housing}

The importance of housing to man can never be over - emphasized but a few of the importance of housing will be discussed under the following headings. 
Provision of shelter/accommodation: The provision of shelter goes beyond the provision of a place for man to rest his head according to Akewusola (2005), it goes as far as provision of safety and security from sunshine, rain, and other harsh weather condition. Furthermore, it protects man from wild animals and their attacks (Kellet and Tipple, 2000)

Investment which yields a flow of income: One of the major reasons why people build houses is to generate income and even make profit from the house when constructed. As a result of this, they plunge into construction of houses which are let out to tenants who in turn pay rents monthly, annually or otherwise as agreed with the landlord (Belton, Fleisher and Chan, 1996). For example, a man who owns a block of ten flats with a monthly rent of $\$ 6,000$ monthly per flat, such man will be making precisely $\$ 60,000$ monthly as rent or $\$ 720,000$ annually. This is indeed real flow of income.

Sign of social prestige: In some communities one of the yardsticks of assessing an individual's achievement is whether he has built a house of his own or not. Any individual who has not attained this status may not be taken seriously within such society. This is because anyone who owns a house of his own according to Barnes (1979) is conferred some social prestige to belong to the class of landlords.

Provision of employment: The construction of houses provides employment for several categories of people whether professionals or artisans (Flavin, 2008). Right from the purchase of the land; the land surveyors is employed to provide the survey plan, then the architect is employed to design the structure; the town planner approves the building drawing; the quantity surveyor provides the bill of quantities and/or estimates and then the builder builds the house. On completion of the project, the estate surveyor takes over the building to let it out to the would be tenants. During the construction process, artisans like bricklayers, iron benders, carpenters, plumbers and electricians are gainfully employed (Angelini and Simmons, 2005)

Provides collateral security for loan: All around the world one of the lending terms for loan taking in banks is the provision of collateral security to the loan amount desired. One of the reasons why the houses meet up this security is because it has a high value whenever it is offered for sale. Also, a house is durable, static, appreciates in value overtime, capable of gathering income and always in high demand. Therefore ownership of a house automatically provides the owner a form of collateral security anytime the desire to apply for a loan.

Durable goods which can be inherited: A house according to Sommer, Sullivan and Verbrugge(2011) is a durable good which can last up to 100 years which means that housing can be transferred from one person to another such as from father to son as a sort of inheritance (Flavin, 2008)

Housing contributes to physical development: The building and their accompanying infrastructure is one single factor that contributes largely to the development of town and cities (Walker, 1993). There is no settlement without houses or buildings. There cannot be meaningful physical development in any place without the construct of houses and roads (Wilson, Hutson and Mujahid, 2008). Apart from the aesthetic of housing estate, 
they constitute a significant percentage of physical development of such cities (Satterthwaite, 1997)

\section{Housing problems in Nigeria}

In Nigeria, an average urban dweller spends between $40-60 \%$ of his income on housing i.e. rents (Nubi 2000), though there is scarcity of data on quantum of housing shortages. While the Federal Ministry of Works and Housing reported that some 5000 housing units annually were projected as required at the national level over the period from 1994 to 2000 to maintain a reasonably dynamic balance in market, Mabogunje (2002) and Okupe (2002) put the figure at 8million while Asunmo and lyagba, (1997) asserted that about 720,000 housing units are needed to be built annually based on an estimate of 9 units yearly per 1,000 population the process of urbanization diversified economic activities. Poor management of activities within the framework of the National Development Programme and the heterogeneous nature of the society in urban centres. Very many Nigerians cannot find an ideal environment or house according to Izomoli, (1997).

Shortage of housing stock both in number and quality virtually abounds in every country particularly in the developing or otherwise called third world countries, this shortage is acute in urban centre. Akewusola (2005) observed that people that sleeps outside houses in Lagos are more than people who sleep inside houses. Thus, it is assertive to say that there is inadequacy of housing stock to cope with the ever increasing population and available housing facilities in Lagos State. (Arayela, 2000) opines the causes of this dearth in housing stock are numerous and also vary from country to country. Homelessness and the incidence of people living in poor housing and unhealthy neighborhoods are in rapid succession in Lagos State. Such place is usually referred to as ghetto areas or slums. The housing problem is much more acute in the urban areas due to the continual influx of people into cities and shortage of affordable housing for the low - income households and poor, who constitutes over 70 percent of the urban population. This has resulted in proliferation of slums and squatter settlements.

Though, numerous studies have been conducted to find more environmentally sustainable solutions however, the results often require expensive, advanced technology and an established standardized community system all of which are not expedient in many developing countries. With increase in population, the need arise to provide development facilities to meet the need of man. Thus modern technology initiatives emerged to replace standard housing (Onibokun 1985).

One of the great challenges facing metropolitan Lagos is housing (Abiodun 1974, 1976). The considerable gap between supply and demand has found expression in the astronomical cost of rented dwellings. Over crowding, slums, and substandard housing are expressions of this problem. Prior to 1928, planned residential areas in Lagos were limited. They included Ikoyi which was a reservation area for expatriates who were colonial administrators and executives of foreign firms, and had a population of 4,000, or 3 percent of the population of the city in 1931. Apapa, Ebute metta and Yaba, with combined population of 22,000, or 17 percent of the total, also had some element of planning, in the sense that road network in Ebute metta and Yaba were laid out on a grid and residential development was confined to the blocks within the road pattern. On Lagos Island, apart from the areas around the Racecourse and Marina, the indigenous housing was unplanned and left to develop haphazardly, with houses built quite close 
together. Such over crowded, unhealthy housing and poor environmental condition stimulated the rapid spread of influenza epidemics, in 1928, of the pioneer planning authority in Nigeria, the Lagos Executive Development Board (LEDB), which embarked on slum clearance and relocation of families from the Island to the Mainland at Surulere (Peil 1991). The period 1979 - 1983 under the Jakande administration witnessed a massive housing development programme. Nevertheless, the problem persists mostly because of rapid population growth.

Despite the efforts of the various housing authorities, 90 percent of the housing in metropolitan Lagos is still provided by the private sector and individual effort. Housing has been widely seen as a secure lucrative investment, which enhances the owner's status in the community (Barnes, 1979) whereas access to privately owned land through customary channels or purchase has made it possible for relatively large stock of owner - occupied housing to be built, opportunities for those excluded from these means of access to land have been limited to areas in public ownership. As a result, squatting is limited and over 60 percent of residents are tenants, some in tenements constructed by absentee landlords, but the majority in houses occupied by landlords of modest means (Peil 1991; Aina Etta and Obi, 1994). During the 1970s it was usual for a man earning the average salary or above to build his own house, while as profit and speculation increased, interest in providing rented rooms for the poor declined. In recent years, declining real wages and high inflation, particularly rapid increases in the prices of building materials have resulted in workers living so close to subsistence level that they have nothing left for investment. Today only the rich construct new housing units. In response to the slower rate of new house construction, tenancy has increased and rents have increased more than five fold since the introduction of the Structural Adjustment Programme (SAP). High densities, over crowding, and multi - family occupancy of dwellings have long characterized Lagos and have intensified in recent years (Ayeni, 1981; Peil, 1991).

\section{Past achievements of Government on public housing}

There was little effort made in field of housing during the pre - independent era and in fact up to the time of the Second National Development Plan Period; except for the central Lagos slum clearance programme and establishment of government reservation areas housing programmes was low in the priority list of the government in the pre independence era (Olayiwola, 2000). The central Lagos slum clearance program displaced about 30,000 people despite the $66.6 \%$ subsidy on housing provided for the displaced, very few if any of the displaced people went to live in the houses because of high cost. During the first National Development plan period only $\$ 39.2$ million representing $47 \%$ of the $\$ 84$ million allocated to urban and regional planning was disbursed. Furthermore, the public sector was only able to produce $1.06 \%$ of the 24,000 housing units planned for this period (Olayiwola, 2000) perhaps, it needs be mentioned too that the former regional governments could not undertake housing scheme on a large scale, even with the establishment of regional housing corporations, because of inadequacy of technical personnel.

The actual achievement of the Second National Development Plan in relation to housing was rather low. The plan was only successful in providing:

a. Ninety staff quarters of various size in Lagos area.

b. Four blocks of flats as transit residence for official of the ministry of external affairs. 
c. The establishment of the Federal Housing Authority in 1973 charged with the provision of low cost housing across the country and

d. The reduction of the interest rate of the Nigerian Building Society from $81 / 2$ to $61 / 2 \%$.

Essentially, it needs to be stated that government effort in the provision of low cost housing in the Second National Development plan period just like in the first was concentrated on Lagos area. The houses themselves were prestigious housing which would be not be tagged public or low income housing as such.

In the Third National Development plan period, the following achievements were recorded:

(a) The promulgation of the rent control edict and the subsequent establishment of the rent control panel charged with the fixing of minimum rent payable on different types of houses.

(b) In 1975, the anti - inflationary task force was established to examine the causes, and consequences of inflation as it pertains to housing.

(c) The promulgation of the land use decree to allow for ease of implementing the public housing programme.

(d) The promulgation of Rent Control edict and the subsequent establishment of the rent control panel charged with the fixing of minimum rent payable on different types of houses.

The Lagos State civilian government constructed 10,428 units out of the planned 50,000 units, were as it completed $70 \%$ of the housing unit meant for the high income groups Alaka, Opebi, Alapere estates. Some of the reason given to low level of housing provision include; poor output of contractors; financial problem arising from current economic situation, unresolved problems of compensation for land structure and crops, un co-operative attitude of some state governors; abandonment of site by contractors; late or non-availability of land, consultancy problems. These factors, the Federal Ministry of Housing and Environment remarked, were reasons why the housing target were not met.

\section{Study area and associated challenges}

Lagos State was created on May 27th 1967 when Nigeria was restructured into 12 States. Before this period Lagos municipality was under the administration of the Federal Government through the Federal Ministry of Lagos Affairs as the regional authority. The city of Lagos was under the Lagos City Council. The regions of Ikeja, Agege, Mushin, Ikorodu were under the former Western Region. The state is located on the SouthWestern part of Nigeria with the southern boundary of the state framed by about 180 Kilometre along Atlantic coastline while the northern and eastern boundaries are framed by Ogun State. The Republic of Benin formed the western boundary. The state is the smallest state in Nigeria in land area with an area of about 358,861 hectares or 3577 sq.km (Odumosu, 1999). This represents only 0.4 percent of the entire area of the country. This size accommodates about 10 per cent of the entire 140 million approximate population of the country. The state is also the most urbanized in Nigeria (Ayeni, 1979). Only about 5 per cent of the state total populations are of rural areas. This has serious consequences on land use planning in the state especially in urban areas.

It also has great implication on infrastructure such as housing, water supply, storm drainage, roads, electricity, telephone, waste management and other socio-economic, cultural and administrative issues. Ironically except for Abuja, Lagos stands out to be the 
best served with infrastructural facilities in the country yet it is where these facilities are most inadequate due to the high population density. The state is also the most affluent in spite of its small size.

Physical and environmental challenges in Lagos can be viewed from both socioeconomic and environmental perspectives. Increase in the urban population has resulted in the proliferation of slums and shantytowns. The proliferation of these shantytowns results in the unwieldy expansion of the urban centres, which poses a major planning problem as the provision and management of roads, drainage and sewage systems among other infrastructure, proves very difficult. Furthermore, shantytowns generate a high rate of poverty, diseases and epidemics, environmental pollution, urban conflicts and crime as typified by Mushin, Ajegunle, Isale Eko, Maroko, Oshodi, Ojo and Orile amongst others. Addressing the problems of the Lagos Metropolis requires a holistic approach. The prevalent problems are physical/environmental, cultural/sociological and managerial (Mabogunje, 1981; Olayiwola, 2000; and Oduwaye and Ogundele, 2006). Incidentally, UN-Habitat (2004) outlines these problems to be the major challenges to poverty reduction in Nigeria. Therefore, these issues must be the fulcrum for any meaningful intervention to the urban development problems of Lagos State.

\section{Research methodology}

The target populations are the private and public housing in Lagos metropolis. Due to the high presence of different kinds of properties, 3-bedroom bungalow buildings were adopted in the collection of data. The data for the study were collected by sourcing information from consulting quantity surveying firms in Lagos state. The data comprises of estimated cost of constructing the typical building based on the prevailing prices during the period in question and index numbers were used to analyse the data. The index of the original figure was produced using the relative method which is given by $P_{n} / P_{o x} 100$. Where $P_{n}$ is the value in the current year, $P_{o}$ is the value in the base year. The annual cost inflation rates, which shows the annual rates of change in construction was also calculated using one sample test to test the hypothesis.

\section{Findings and discussion \\ Findings}

Table 1: Construction cost for typical 3 bedroom bungalow (mass Housing) Lagos

\begin{tabular}{lcccccl}
\hline Year & $\begin{array}{c}\text { Construction } \\
\text { Cost (N 000) }\end{array}$ & $\begin{array}{c}\text { Construction } \\
\text { Cost index } \\
(2000=100)\end{array}$ & $\begin{array}{c}\text { Construction } \\
\text { Cost index } \\
(2007=100)\end{array}$ & $\begin{array}{c}\text { Construction } \\
\text { Cost index } \\
(2009=100)\end{array}$ & $\begin{array}{c}\text { Annual } \\
\text { Inflation rate } \\
(\%)\end{array}$ & \\
\hline 2000 & $7,029.28$ & 100.00 & 54.07 & 37.19 & & \\
2001 & $7,399.24$ & 105.26 & 56.92 & 39.15 & 5.26 & \\
2002 & $7,871.53$ & 111.98 & 60.55 & 41.65 & 6.38 & \\
2003 & $8,556.02$ & 121.27 & 65.82 & 45.27 & 8.70 & \\
2004 & $9,613.50$ & 136.76 & 73.95 & 50.87 & 12.36 \\
2005 & $11,050.00$ & 157.20 & 85.00 & 58.47 & 12.36 \\
2006 & $13,000.00$ & 184.94 & 100.00 & 68.78 & 14.94 \\
2007 & $13,000.00$ & 184.94 & 100.00 & 68.78 & 0.00 & \\
2008 & $16,500.00$ & 234.73 & 126.92 & 87.30 & 26.92 & \\
2009 & $18,900.00$ & 268.88 & 145.38 & 100.00 & 14.55 & \\
\hline
\end{tabular}

The results in the Table 1 show fluctuations in the cost inflation rates with $26.92 \%$ as the highest recorded in the table. The rates were fairly stable between 2001 and 2003. The lowest rate was found in the year 2001 with an annual inflation rate of 
$5.26 \%$. On the table, it was noticed that between 2006 and 2007 there was no change in annual inflation rate. The year 2008 displayed contrasting sharp rise in annual inflation rate.

Table 2: One -sample T-test results (Annual Inflation)

\begin{tabular}{ccccccc}
\hline Year & $N$ & Mean & $\begin{array}{c}\text { standard } \\
\text { Deviation }\end{array}$ & $\begin{array}{c}\text { T-Statistic } \\
\text { Test Value }=0\end{array}$ & $\begin{array}{r}\text { DF } \\
\text { At } \alpha=\end{array}$ \\
\hline $2000-2009$ & 9 & 11.27 & 7.63 & 4.436 & 8 & 0.002 \\
$2000-2007$ & 7 & 8.57 & 5.14 & 4.412 & 6 & 0.005 \\
$2007-2009$ & 3 & 13.82 & 13.47 & 1.777 & 2 & 0.218 \\
\hline
\end{tabular}

One -tailed, one sample t-test was carried out on the data collected as shown in Table 2 compared with the critical $t$ values and alpha levels at which the results were significant as shown. The mean inflation rates for all period are double digit, 2007 to 2009 has the highest annual cost inflation rate of $13.82 \%$, while 2000 to 2007 has the lowest inflation rate of $8.57 \%$. However, 2007 to 2009 has the highest standard deviation of 13.47, while 2000 to 2007 has the lowest standard deviation of 5.14. The annual housing cost inflation has the highest rate of increase during the period of 2004 to 2008. It has the lowest rate of increase in annual housing cost inflation during the period of 2000 to 2003. Also in table 1, it was noticed that there was no change in annual cost inflation rate (\%) in the year 2007, it has a value of $0.00 \%$ which indicate no change. This $0.00 \%$ change in annual inflation rate occurred because it was during this period there was a change in government between Olusegun Obasanjo and (late) Umaru Musa Yar'adua.

Table 3: One-sample T-test results (index-number)

\begin{tabular}{lcccccr} 
Year & $N$ & Mean & $\begin{array}{c}\text { Standard } \\
\text { Deviation }\end{array}$ & $\begin{array}{c}\text { T-Statistic } \\
\text { Test value }=100\end{array}$ & DF & Significant \\
\hline $2000-2009$ & 9 & 167.38 & 56.47 & 3.580 & 8 & 0.007 \\
$2000-2007$ & 7 & 143.26 & 33.16 & 3.451 & 6 & 0.014 \\
$2007-2009$ & 3 & 129.52 & 42.21 & 5.814 & 2 & 0.034 \\
\hline
\end{tabular}

The t-statistic for the periods in table 3 are significant at 0.005 level. The t- statistics also show that annual cost inflation for the period 2000-2009 is highly significant and is the most statistically significant (significant at 0.002 level ) while that of 2007-2009 is the least (at 0.218 level) there is therefore a strong evidence that housing construction cost were escalating annually between 2000-2009.

\section{Index Numbers}

The index number on table 1 shows upward trends throughout the period, this was increasing steadily from 100 in 2000 to 184.94 in 2007, but between 2008 and 2009 there was an increase in the cost of housing, having a value of 234.73 to 268.88. The cost in 2007 was $184.94 \%$ and $68.78 \%$ based on the year 2000 and 2009 prices 
respectively. While the cost in 2009 are $268.88 \%$ and $145.38 \%$ prices respectively. The cost of housing construction was high in 2009, this increase in cost indicate escalation of construction cost during the period. The data to test the second null hypothesis for the various periods are shown below. The test was carried out using SPSS15 and the alpha level at which they were significant are shown in table 3.

The $t$ statistics for all the period are significant at 0.05 level. The inference is that the inflations in housing construction cost during the periods analyzed are significant. Therefore it can be seen that the inflation during the period 2000 to 2009 is highly significant while that of 2007 to 2009 is least significant. The conclusion therefore is that there was escalation of housing construction cost between 2000 and 2009. It was noticed that during 2007 there was no increase in the annual inflation cost of housing construction cost in Lagos.

\section{Discussion of findings}

The increase in cost of housing construction was due to high inflation rates in the prices of building materials. In particular and in the economy in general, the cost of materials and labour is continually on the increase, this increase has gone beyond the reach of many Nigerians. The Nigerian housing is primarily that of a crisis situation, manifesting and expressing itself in quantitative and qualitative forms. Lack of comfort and rudimentary infrastructure, congestion, unhygienic conditions, high densities and absence of organization make for ghastly experiences shared by the vast majority of the urban population. The spatial product of this problem is not in the rapid emergence and deployment of slums and squatter of various typologies but in the proliferation of these settlements in the metropolitan suburb. The discussion and debates on the Nigerian housing situation have always been anchored on the need for continuous state intervention through public housing provision in solving the crisis. Public housing provision is not only a social and environmental necessity but also a political and economic approach necessary to support social peace and stable development in the nations of the world.

Research has shown that $75 \%$ of urban housing is situated in slum conditions (Uurban Development Policies in Nigeria, 2008), and indeed the quality of the housing is poor and clearly an affront to human dignity (Olotuah, 1997; Agbola and Olatubara, 2003). As part of effort to increasing qualitative housing for the masses in the country, the Federal government in 2004, pledged to adequately fund research pertaining to the manufacture and the use of local materials in the sector with the aim of providing 40,000 houses with at least 1,000 per state before year 2007. Unfortunately, the private sector is saddled with numerous problems which make supply always fall for short of demand and lower production quality (Nubi, 2008). The problem of qualitative housing has been a concern for both the government and individuals. Appreciating these problems, both the public and private sector developers make effort through various activities to bridge the gap between housing supply and demand but the cost of building materials, deficiency of housing finance arrangement, stringent loan conditions from mortgage banks, government policies amongst other problems have affecting housing delivery significantly in Nigeria (Raji, 2008).

\section{Conclusion and recommendations}

Nigerian cannot stand aloof to the responsibility of standing up to the needs of her estimated 160 million people. From the discussion presented, it is arguable that Nigerian 
housing crisis is not deficient of solution in practical and theoretical term. The problem is no longer in the search for effective, feasible and viable policies but where the thrust of the issues lies seems to be in the political will, economic determination, organized and democratic approaches in the resolution of housing crisis. Housing construction cost has risen over time, it has been escalating since 2000 and the inflation between 2000 and 2009 is statistically highly significant. Government policies and programmes have strong impact on housing construction cost because of high level of government involvement in the construction industry.

It is recommended that government should deal with the cost of inflation so as to cut down the high prices of building materials which causes incessant increase in housing construction cost in the economy. Public housing should be provided so as to necessitate political and economical approach necessary to support social peace and stable development in our economy. There should be provision of basic infrastructure in various layouts on which individuals could build their own houses.

\section{References}

Abiodun, J. O. (1974). Urban growth and problems in Metropolitan Lagos. Urban Studies 11:341-347.

Abiodun, J. O. (1976). Housing problems in Nigerian cities. Town Planning Review 47(4): 330-348.

Abiola, R. O. (2000). Management implications of trends in construction cost in Nigeria from 1989 to 1999, The Quantity Surveyor,30, 35-40.

Achuenu, E and Gundiri, F. B. (1998). Contract price escalation in Nigerian building industry, Journal of environmental sciences 2(1): 10-15.

Agbola, T. and Olatubara, C. O. (2003), "Private sector driven housing delivery (in Nigeria): Issues, constraints, challenges and prospects", a lead paper presented at the 2nd Annual National Workshop on Private sector Driven Housing Delivery in Nigeria, University of Lagos, Lagos, 30th June - 3rd July.

Aina, T. A., F. E. Etta, and Obi. C. I. (1994). The search for sustainable urban development in Metropolitan Lagos, Nigeria: Prospects and problems. Third World Planning Review 16: 201-219.

Akewusola, W. A. O. (2005). Housing for all by the year 2015, a realistic point of view, The Quantity Surveyor, 52(3), 29-34

Angelini, V. And Simmons, P. (2005). Housing debt, employment risk and consumption. Discussion paper in Economics at the University of York, Heslington, No 2005/07, $1-35$

Arayela, O. (2000). Increasing housing stock at reduced cost in Nigeria. AARCHES J. 2(2). 18-24

Asumo, B. and lyagba, R. (1997). Housing crisis in Nigeria's urban areas- a challenge to the construction industry and technology. The Lagos Journal of Environmental studies. 1, 39-47.

Ayeni, B. (1979). Concepts and Technologies in Urban Analysis. London: Croom Helm. 
Ayeni, B. (1981). Lagos. In: M. Pacione, ed., Problems and Planning in Third World Cities. Croom Helm, London, pp. 127-155.

Barnes, S. T. (1979). Migration and land acquisition: The new landowners of Lagos. African Urban Studies 4: 59-70.

Belton, M., Fleisher and Chan, J. (1996). The Coast-Non-Coast Income Gap, Productivity and Regional Economic Policy in China, Retrieved from www.econ.ohio-state.edu/pdf/coastal.pdf

Egunjobi, L. (1999). The gasping city. Inaugural Lecture, University of Ibadan

Federal Office of Statistics (1997). Society of economic profile of Nigeria 1996.Lagos

Flavin, M. and Nakagowa (2008). A model of Housing in the presence of adjustment costs: A structural interpretation of habitat persistence, American Economic Review, 98(1), 474-495

Izomoli, S.O. (1997). Housing provision and management in Nigeria.Emiola Publisher, Ogbomoso.

Kellet, P. And Tipple, G. A. (2000). The home as workplace: a study of incomegenerating activities within the domestic settings, Environment and Urbanization, 12(1), 203-214

Mabogunje, A. L. (1981). Economic analysis of housing trait price in a third World City, regional sciences, 26, 533-547.

Mabogunje, A. L. (2002). Inaugural address made at the first general meeting of royal Estate Developers Association of Nigeria. Abuja, Nigeria.

Nubi, O. T. (2008). Affordable Housing Delivery in Nigeria. The South African Foundation International conference and exhibition. Cape town, October, Pp1-18.

Nubi, O. T. (2000). Financing urban housing. Being a paper delivered in a workshop organized by Nigerian building and road research institute (NBRI).

Nwuba, C. C. (1992). The dilemma of urban tenants. The financial (Lagos) 4(15), 4-5.

Nwuba,C. C (1994). Management property in a depressed economy estate surveyor and valuers. Journal of the Nigerian institution of estate surveyor valuers 18(2):14-19.

Odumosu, T. (1999). Location and Regional Setting of Lagos State. Lagos State in Maps. Balogun T., T. Odumosu and K. Ojo (eds). Ibadan;Rex Charles.

Oduwaye, L. and Ogundele, K. (2006). Environmental Hazards in Metropolitan Lagos. A Conference proceedings on Conflict Resolution and Environmental, Economics, Department of Estate Management University of Lagos.

Okupe, L. (2002). The Role of the Private Sector in Housing Delivery in Nigeria. In Proceedings of a 2-Day National Seminar of the Nigerian Institute of Building, Ibadan, edited by Adesanya, A., 18 - 40.

Okupe, L. (2000). The Role of the Private Sector in Housing Delivery in Nigeria. In Proceedings of a 2-Day National Seminar of the Nigerian Institute of Building, Ibadan, edited by Adesanya, A., $14-29$. 
Olayiwola, L. M. (2000). Technique for achieving sustainable development for Towns and cities in Osun State: A workshop proceeding on Urban Planning and Sustainable Development in Osun State. Frontline Consultants. 1 - 15.

Olutuah A. O. (1997). The House: Accessibility and Development-A critical evaluation of the Nigerian situation. Proceedings of National symposia on Housing in Nigeria. Obafemi Awolowo University Ile Ife, 312-317

Onibokun, A. G. (1985). Urban Housing problems: implication for construction industry in A.G. Onibokun (ed), urban housing in Nigeria. 39-57

Peil, M. (1991). Lagos: The City Is the People. Belhaven Press, London.

Raji, O. (2008). Public and private developers as agents in Urban Housing delivery in sub-Saharan Africa. The situation in Lagos state, Humanity of social sciences Journal, 3(2) 143-150.

Satterthwaite, D. (1997). Sustainable cities or cities that contribute to sustainable development?, Urban Studies, 34(10), 1667-1691

Sommer, K., Sullivan, P. And Verbrugge, R. (2011). Run-up in the house price rent ratio: How much can be explained by fundamentals? HUML conference at the Federal Reserve Bank of Chicago

Udegbe, M. I. (2005). Labour Force Output on Plastering Activity in Edo State, The Professional Builder, 7, $34-41$.

UNCHS, (1996). An Urbanizing World: Global Report on Human Settlements. Oxford: Oxford University Press.

UN-Habitat, (2004). City Development Strategies: Lessons from UMP/UN-HABITAT Experiences. UMP Series 29. Nairobi; UN-HABITAT.

Urban Development Policies in Nigeria (2008). Planning, Housing and Land Policy; A report of the Centre for Economic Research on Africa. December, 1-12.

Walker, C. (1993). Non-profit Housing Development: Status, Trends and Prospects, Housing Policy debate, 4(3), 369-414

WCED, (1987). Our Common Future, Oxford: Oxford University Pres.

Wilson, S., Hutson, M. And Mujahid, M. (2008). How planning and zoning contribute to inequitable development, neighbourhood health and environmental injustice, Environment Justice, 1(4), 211-216

Windapo, A. O. (2004). Meeting Housing Needs in a Developing and Deregulated Economy - Nigeria, The Professional Builder, 6, 34 - 41. 